\title{
Review \\ Advances in estrogen receptor biology: prospects for improvements in targeted breast cancer therapy
}

\author{
Wenlin Shao and Myles Brown
}

\begin{abstract}
Division of Molecular and Cellular Oncology, Department of Medical Oncology, Dana-Farber Cancer Institute, and Department of Medicine, Brigham and Women's Hospital and Harvard Medical School, Boston, MA, USA
\end{abstract}

Corresponding author: Myles Brown (e-mail: myles_brown@dfci.harvard.edu)

Published: 7 November 2003

Breast Cancer Res 2004, 6:39-52 (DOI 10.1186/bcr742)

(c) 2004 BioMed Central Ltd (Print ISSN 1465-5411; Online ISSN 1465-542X)

\begin{abstract}
Estrogen receptor (ER) has a crucial role in normal breast development and is expressed in the most common breast cancer subtypes. Importantly, its expression is very highly predictive for response to endocrine therapy. Current endocrine therapies for ER-positive breast cancers target ER function at multiple levels. These include targeting the level of estrogen, blocking estrogen action at the ER, and decreasing ER levels. However, the ultimate effectiveness of therapy is limited by either intrinsic or acquired resistance. Identifying the factors and pathways responsible for sensitivity and resistance remains a challenge in improving the treatment of breast cancer. With a better understanding of coordinated action of ER, its coregulatory factors, and the influence of other intracellular signaling cascades, improvements in breast cancer therapy are emerging.
\end{abstract}

Keywords: coregulators, estrogen receptor, growth factors, SERM, tamoxifen resistance

\section{Introduction}

Estrogen receptors (ERs) are members of the nuclear receptor (NR) superfamily that mediate the pleiotropic effects of the steroid hormone estrogen in a diverse range of developmental and physiological processes [1]. Although estrogens are important physiological regulators in the reproductive system, in bone metabolism, and in the maintenance of the cardiovascular and central nervous systems, they have also been associated pathologically with an increased risk for breast and endometrial cancer [2-5]. Consequently, ERs have been found to be essential in the initiation and development of most of these cancers. Current endocrine therapies for ER-positive breast cancers are primarily designed to target either estrogen or ER levels and/or activity. Use of a partial antiestrogen, tamoxifen, in the management of early-stage breast cancer has clearly demonstrated an increase in both disease-free and overall survival. In addition, recent studies demonstrate that tamoxifen can be used as a chemopreventive agent for hormone-dependent breast cancer. The major concerns of long-term therapy with tamoxifen are its uterotropic effects, which result in an increased risk for endometrial cancer, and the acquired clinical resistance to tamoxifen. This has led to the active pursuit of better selective ER modulators (SERMs) that display the optimal agonistic or antagonistic activities in various estrogen target tissues.

In this article we review the emerging studies of ER action that reveal the roles of a wide spectrum of receptor coregulators and their interaction with other cellular signaling pathways. An understanding of the molecular factors that modulate the activity of the estrogen-signaling network provides insight into the mechanism by which SERMs exert their tissue-specific effects. The identification of factors that are responsible for such effects is enabling the development of new ways to overcome resistance to endocrine therapy.

AIB1 = amplified in breast cancer; AF-1 = activation function-1; AF-2 = activation function-2; cAMP = cyclic AMP; CBP = CREB-binding protein; $\mathrm{DES}=$ diethylstilbestrol; E2 = 17 $\beta$-estradiol; $\mathrm{ER}=$ estrogen receptor; $\mathrm{ERE}=$ estrogen response element; $\mathrm{EGF}=$ epidermal growth factor; $\mathrm{EGFR}=$ epidermal growth factor receptor; FDA = Food and Drug Administration; HAT = histone acetyltransferase; IGF1 = insulin-like growth factor-1; LBD = ligand-binding domain; MAPK = mitogen-activated protein kinase; NR = nuclear receptor; PKA = protein kinase $A$; SERM = selective estrogen receptor modulator. 


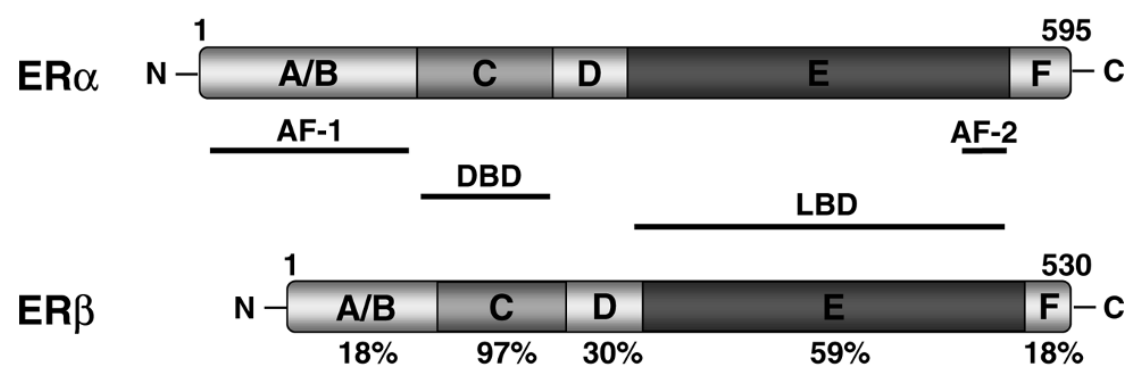

Schematic diagram of the two human estrogen receptors, ER $\alpha$ and ER $\beta$. Both receptors consist of six functional domains, including the DNAbinding domain (DBD), the ligand-binding domain (LBD), the ligand-independent activation function AF-1, and the ligand-dependent activation function AF-2. The percentage identity between the two receptors is indicated.

\section{$E R \alpha$ and ER $\beta:$ structure}

Two mammalian ERs have been identified, ER $\alpha$ and ER $\beta$, encoded by independent genes [6-8]. ER $\alpha$ was cloned nearly two decades ago and was believed for many years to be the only ER. The subsequent cloning of ER $\beta$ increased the complexity of estrogen signaling. Both ER isoforms share modular structures characteristic of the NR superfamily, which include six functional domains (Fig. 1) [9]. The most conserved domain is the central DNAbinding domain (DBD, region $C$ ), followed by the ligandbinding domain (LBD, region E). The LBD also contains a dimerization surface and a ligand-dependent activation function 2 (AF-2). AF-2 undergoes a marked conformational change in the presence of different ligands, and determines the subsequent binding of coactivators or corepressors. Activation function 1 (AF-1), located in the $\mathrm{N}$-terminal $\mathrm{A} / \mathrm{B}$ domain, is regulated by growth factors and its activity depends on the cellular and promoter context. AF-1 and AF-2 act synergistically to attain maximal receptor transcriptional activity. Although both ER $\alpha$ and ER $\beta$ display similar binding affinities for $17 \beta$-estradiol (E2), they have different roles in the regulation of gene expression. The low level of conservation within the $A / B$ domains of $\mathrm{ER} \alpha$ and $\mathrm{ER} \beta$ might be responsible for these functional differences between the two receptors by interacting with unique sets of transcription factors.

ER exerts its transcriptional effects through both direct and indirect binding to specific DNA sites, termed estrogen response elements (EREs), located in the promoter and/or enhancer regions of target genes [10]. The consensus EREs consist of two inverted, palindromic halfsites of PuGGTCA motifs. ER can bind EREs as ER $\alpha$ or ER $\beta$ homodimers or as ER $\alpha \beta$ heterodimers. The affinity and the specificity of ER binding are determined by both the sequence and spatial organization of the motifs $[11,12]$. In addition to signaling directly through EREs, ER can act more as a coactivator to modulate transcriptional bound transcription factors, such as AP-1 or SP-1 $[13,14]$. These different modes of ER action have been suggested to have an important role in determining differential responses to various ER ligands.

\section{Ligand-dependent ER-mediated transcription: coregulators}

It is now recognized that ER-mediated transcription is a highly complex process involving a multitude of coregulatory factors and 'cross-talk' between distinct signaling pathways (Fig. 2) (reviewed in [15]). The existence of intermediary factors in the ER action was suggested by several observations, including the tissue-specific activities of tamoxifen and the cross-squelching observed between cotransfected receptors in transcription assays. By following this lead and using biochemical approaches as well as yeast two-hybrid screens, over 30 coregulatory molecules have been identified. For simplicity they can be broadly divided into coactivators, which augment the activity of receptors, and corepressors, which mediate the repressive effects of receptors (reviewed in [16]).

Transcriptional activation involves alterations in chromatin structure mediated by ATP-dependent chromatin-remodeling enzymes in conjunction with factors that contain histone acetyltransferase (HAT) activity [17]. Consistent with this concept is the observation that ER recruits BRG1, a mammalian homologue of a component of the SWI/SNF chromatin remodeling complex, to EREs in a cooperative manner with HATs [18]. Further, many ER coactivators possess intrinsic HAT activities, including $\mathrm{CBP} / \mathrm{p} 300, \mathrm{p} / \mathrm{CAF}$, and $\mathrm{TAF}_{\|} 250$ [19-21]. Other coactivators such as the p160 coactivators facilitate ER transcription by serving as platforms to recruit HATs and protein methyltransferases.

There are three members of the $\mathrm{p} 160$ family of coactivators, NCoA-1 (SRC-1) [22], NCoA-2 (TIF2, GRIP1) $[23,24]$, and NCoA-3 (AIB1, ACTR, RAC3, p/CIP, 


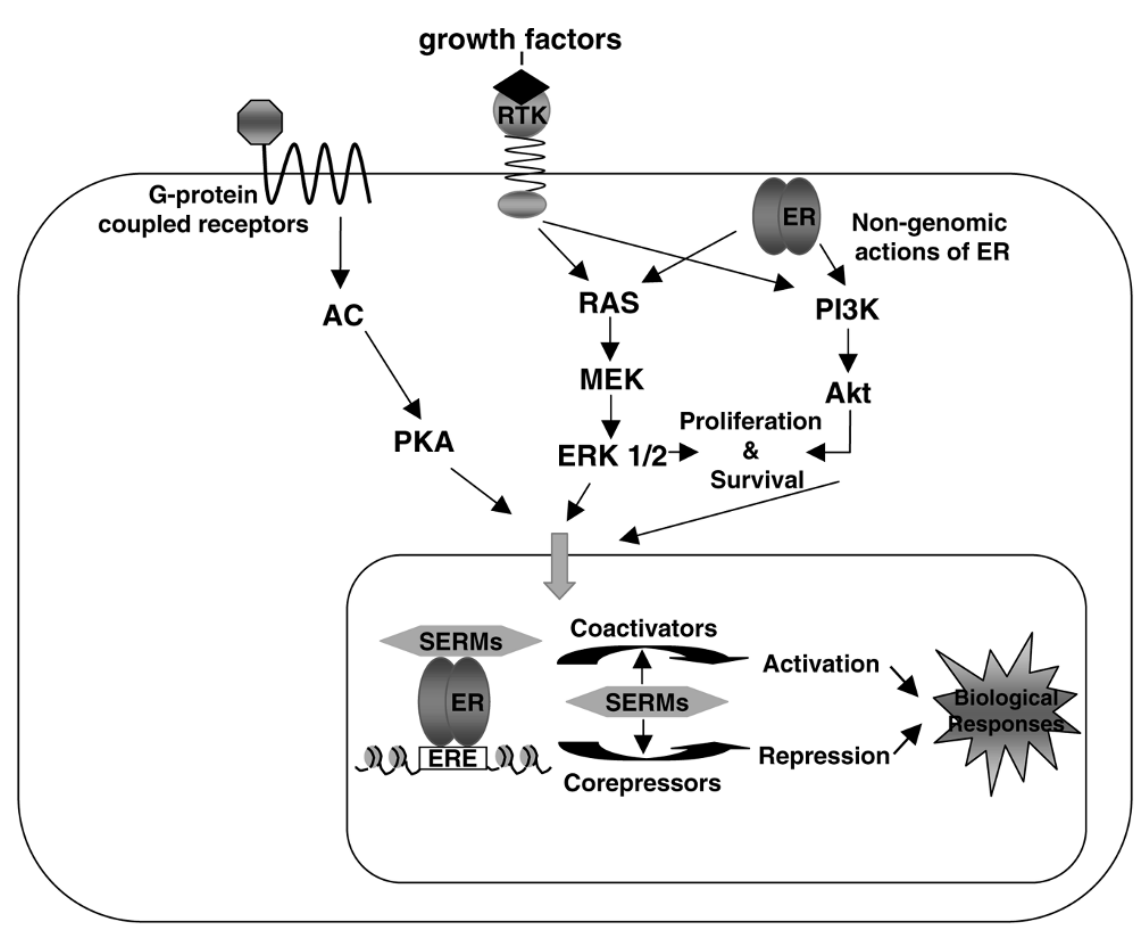

ER regulation by a variety of signals. Growth factors such as epidermal growth factor, insulin-like growth factor-1, insulin, and transforming growth factor- $\beta$ bind to and activate their receptors, which in turn activate the RAS-RAF-ERK and the phosphoinositide 3-kinase (PI3K) pathways; the activated kinases then phosphorylate and activate ER. Other extracellular stimuli such as dopamine and cyclic AMP bind G-protein-coupled receptors and activate adenylyl cyclase (AC) and protein kinase $A(P K A)$, which subsequently phosphorylate and activate ER. ER can also interact directly with components of the cytosolic signaling molecules, including the regulatory subunit of PI3K, leading to the activation of the serine/threonine kinase Akt. In the nucleus, hormone binding results in receptor dimerization and recruitment of coactivators or corepressors depending on the bound ligand, leading to transcriptional activation or repression. ERE, estrogen response element; MEK, MAP kinase/ERK kinase; SERM, selective estrogen receptor modulator.

TRAM-1) [25-30], which share extensive structural homology. They all contain a bHLH-PAS (basic helix-loop-helix-Per/ARNT/Sim) domain in the amino-terminus. Although this domain mediates DNA binding in other factors that contain it, no evidence of direct contact of the p160 coactivators with DNA has been demonstrated. In the central region of the $\mathrm{p} 160$ proteins there is a domain that mediates the interaction of $p 160$ coactivators to the LBD of agonist-bound ER through several short helical motifs with the sequence LXXLL [31]. The C-terminal region of the $\mathrm{p} 160$ proteins mediates interaction with other factors with a role in ER signaling including CBP (CREB-binding protein), p300 and arginine methyltransferase 1 (CARM-1) [32].

In spite of significant sequence homology between p160 members, several lines of evidence suggest that in addition to some degree of functional redundancy they have unique functions as well. Although all three p160 coactivators are widely expressed at low levels in a number of tissues, they exhibit high levels of expression in selective tissues. NCoA-1 has relatively high levels of expression in the brain and pituitary [33], whereas NCoA-2 has the highest levels in the testis [23], and NCoA-3 in the thyroid gland, thymus, kidney, lung, and skin [34]. Further, the levels of expression of these coactivators are hormonally regulated. For example, thyroid hormone upregulates NCoA-1 mRNA levels in the anterior pituitary, whereas E2 downregulates its expression [33]. Both the mRNA and protein levels of NCoA-3 can be suppressed by E2, and this repression is reversed by antiestrogens or all-trans retinoic acid [35].

More evidence of their distinct physiological functions comes from knockout mouse models. Deletion of the gene encoding NCoA-1 in mice resulted in only mild defects in hormone target tissues such as uterus, mammary gland, testis, and prostate. These tissues exhibit decreased growth and development in response to steroid hormones in the absence of NCoA-1 [36]. In addition, disruption of NCoA-1 causes a delay in Purkinje cell development and the maturation of the cerebellum leading to moderate motor dysfunction in adulthood [37]. Genetic deletion of NCoA-3 leads to a different spectrum of phenotypes, 
including stunted somatic growth, delayed puberty, abnormal reproductive function and retarded mammary ductal growth $[34,38]$. The more severe defects observed in the mammary gland in these mice suggests that $\mathrm{NCoA}-3$ might have a more pronounced role in regulating mammary gland functions.

In addition to the chromatin remodeling complexes and the p160 family, a wide spectrum of coactivators has been found to interact with ER. These include DRIP205/ TRAP220/PBP, a component of the DRIP/TRAP mediator complex [39-41], PGC-1, a tissue- and promoter-specific PPAR $\gamma$-coactivator-1 [42,43], SNURF, a small nuclear $\mathrm{C}(3) \mathrm{HC}$ (4) finger protein [44], PELP1, a proline-, glutamic acid-, leucine-rich protein 1 [45], and NCoA-7 (ERAP140), a structurally distinct coactivator [46]. With the exception of NCoA-7, most of these coactivators possess the canonical LXXLL motif that mediates their agonist-induced interaction with the ER LBD. The common mode of interaction of a large number of coactivators involving the LXXLL motif with most of the nuclear receptor raises the problem of a potential lack of specificity. One solution to this problem might be that sequences flanking the core motif can determine receptor selectivity, as suggested by phage display experiments [47].

In contrast to these factors that all bind to the ER LBD, some coactivators, such as the steroid receptor RNA activator SRA and the RNA helicases p68/p72, interact with and regulate the AF-1 domain of ER [48-50]. GT198, a tissue-specific and kinase-regulated coactivator, interacts with the ER DNA-binding domain. GT198 differs from other coactivators in that it regulates basal receptor activity and hormone sensitivity [51]. Some ER-interacting proteins have other distinct biological functions. Cyclin D1, a protein frequently overexpressed in breast cancer, has been shown to activate unliganded ER through recruiting p160 coactivators and p/CAF [52-55]. The calciumbinding protein calmodulin and the activating enzyme of NEDD8, Uba3, both regulate ER activity by modulating the steady-state level of the receptor $[56,57]$. The Sma and MAD-related protein 3 (SMAD3) interacts with ER, allowing cross-talk between the estrogen and the transforming growth factor- $\beta$ signaling pathways [58]. Similarly, MNAR, a modulator of nongenomic activity of ER, modulates ER interaction with members of the Src family of tyrosine kinases, leading to stimulation of their enzymatic activity, which in turn enhances ER transcriptional activity [59].

Opposing the mechanism by which coactivators effect transcriptional activation by modulating chromatin state, NR corepressors negatively regulate transcription via their recruitment of histone deacetylases (HDACs). The best characterized corepressors are the structurally related proteins N-CoR and SMRT, which interact with the repressive form of nuclear receptors such as the unliganded retinoic acid and thyroid hormone receptors [60,61]. In the case of ER, both N-CoR and SMRT bind ER in the presence of antagonists such as tamoxifen and are recruited to the promoter of target genes [62-65]. Other proteins act to repress ER-mediated transcription by distinct mechanisms [66-69]. Examples include the ER-specific corepressor REA, as well as the orphan receptors SHP and DAX-1, which act by competing with the p160 coactivators for binding agonist-bound ER.

\section{Structure of the ER LBD}

Complementing the molecular studies of ER regulation, structural analyses of the ER LBD have shed further light on our understanding of ER function, in particular its interaction with coactivators and the structural basis of receptor agonism and antagonism. A wide repertoire of structurally and chemically distinct compounds bind to ER. Some of these compounds, such as the natural ligand E2 and the synthetic diethylstilbestrol (DES), act as receptor agonists, whereas others compete for E2 binding and act as antagonists. Structural studies of the ER LBD have established that ER ligands have a profound effect on the receptor structure. The structure of ERLBD exhibits a $\alpha$-helical sandwich topology distinctive of NR LBDs: it consists of 12 helices $(\mathrm{H} 1-\mathrm{H} 12)$ arranged in three antiparallel layers separated by $\beta$-sheets [70]. Although the overall conformation of the ER LBD is quite similar in the presence of various compounds, the carboxy-terminal transactivation domain (AF-2, H12) is highly sensitive to the nature of the bound ligand.

Structures of ERLBD in complex with E2, DES, the SERMs raloxifene and tamoxifen, and the pure antiestrogen ICl 164,384, an analogue of fulvestrant (ICl 182,780), have been determined [71-74]. ER agonists induce a major conformational change in the receptor: $\mathrm{H} 12$ is repositioned and aligned over the ligand-binding cavity, resulting in a specific binding site for the consensus LXXLL motif of the coactivators $[75,76]$. However, binding of raloxifene or tamoxifen sterically hinders the $\mathrm{H} 12$ positioning and prevents the formation of the coactivator-binding surface [71-73]. The pure antiestrogen ICl 164,384 elicits an unusual organization of the LBD [74]. ICI 164,384 is a $7 \alpha$-alkylamide analog of E2 and its protruding $7 \alpha$ sidechain substituent sterically prevents $\mathrm{H} 12$ from aligning over the ligand-binding cavity; further, the positioning of the terminal amide portion of the sidechain occludes $\mathrm{H} 12$ from adopting its alternative position over the coactivator-binding cleft. Consequently, ICl 164,384 seems to completely abolish $\mathrm{H} 12$ association with the LBD, which might be crucial for generating its full antagonist effect. However, our increased understanding of the structural changes induced by various ER ligands has yet to allow the design of a SERM with an optimal balance between the agonistic and antagonistic properties in the desired target tissues. 


\section{Ligand-independent ER activation: cross-talk with other signaling pathways}

ER regulation is not limited to direct ligand binding, because it can also be modulated by several other pathways. These include the epidermal growth factor (EGF) and insulin-like growth factor-1 (IGF1) mitogenic pathways and the second messengers cyclic AMP (cAMP) and dopamine (reviewed in [77-79]) (Fig. 2). Activation of these pathways influences ER transcriptional activity either by targeting the receptor directly or by regulating the activities of receptor coregulators. For instance, activation of epidermal growth factor receptor (EGFR) by EGF leads to phosphorylation of the Ser118 residue in the ER $\alpha$ AF-1 domain by $\mathrm{p} 44 / 42$ mitogen-activated protein kinase (MAPK), which in turn recruits the coactivator p68/p72 and activates target gene transcription in a ligand-independent manner $[80,81]$. In contrast, ligand-dependent S118 phosphorylation is mediated through the association of ER $\alpha$ with TFIIH and the cyclin-dependent kinase CDK7 [82,83]. In addition, the activation of protein kinase $A$ (PKA) by CAMP results in ER phosphorylation and increased transactivation of an ERE-containing reporter $[84,85]$. One report suggests that Ser236 phosphorylation by PKA inhibits ER dimerization, and this inhibition can be reversed by E2 [86].

ER coregulators are also targets of many of the same signaling pathways that affect ER directly. MAPK can phosphorylate p160 coactivators $\mathrm{NCoA}-1$ and $\mathrm{NCoA}-3$, and can enhance their transcriptional activities partly by facilitating their interaction with CBP/p300 $[87,88]$. CBP itself can also be phosphorylated and activated through the p42/44 MAPK cascade [89-91]. Phosphorylation of CBP by both MAPK [92] and cyclin-dependent kinases (CDKs) leads to an upregulation of its HAT activity [93].

Although it has been well established that growth factors can modulate ER transcriptional activity, the observation that activated ER can transmit signals that modulate these signal transduction pathways has been more difficult to dissect. Studies suggest that E2-bound ER can activate the extracellular signal-regulated kinase (ERK) or the phosphoinositide 3-kinase (PI3K), leading to the activation of downstream signaling molecules [94,95]. The existence of transcription-independent ER functions increases the potential diversity of ER signaling. It remains to be determined which physiological and pathological activities of ER are dependent on its non-genomic activities.

\section{ER and breast cancer}

An important role for ER in breast cancer has been known for almost 30 years [96]. Although both $E R \alpha$ and ER $\beta$ have been implicated, the role of ER $\beta$ in breast cancer remains elusive (reviewed in [97]). ER $\alpha$ is expressed in a subset of normal breast epithelial cells, and ER $\alpha$-containing epithelial cells do not normally proliferate in response to estrogen [98]. In this view, estrogen stimulates the normal mammary epithelium to secrete growth factors that stimulate neighboring ER-negative epithelial cells to proliferate in a paracrine fashion. In contrast to the normal breast, most pre-malignant breast lesions express high levels of ER $\alpha$, and ER $\alpha$-expressing breast cancer cells are hormone-dependent and undergo regression when estrogen is removed (reviewed in [99]). Thus, ER $\alpha$ is a wellestablished predictive marker of hormone sensitivity in breast cancer as well as a positive prognostic marker. Further, the presence of ER $\alpha$ in breast cancer at the time of diagnosis is an indication for endocrine therapy. In the advanced disease setting, many patients with ER $\alpha$-positive breast tumors will respond favorably, at least initially, to endocrine therapies.

Because ER-positive breast cancer is estrogen-dependent, reducing estrogen levels or altering the activity of the receptor can induce these cancers to regress. Oophorectomy remains an option for premenopausal women with ER-positive tumors; however, medical rather than surgical approaches are more widely used. Current approaches designed to reduce levels of circulating estrogen include selective aromatase inhibitors and luteinizing-hormonereleasing hormone (LHRH) agonists. Drugs that target ER fall into two major classes. These include SERMs such as tamoxifen and the pure antiestrogens such as fulvestrant, which reduce ER concentrations.

Menopausal status has an important role in determining therapy (Fig. 3). Small, randomized trials in premenopausal women have suggested that tamoxifen brings treatment benefits similar to those with oophorectomy. Moreover, tamoxifen can be used effectively as a second-line endocrine therapy after oophorectomy, and vice versa $[100,101]$. In postmenopausal women, the primary source of estrogen is not from ovarian synthesis but from the conversion of androstenedione to estrone and estradiol in the peripheral tissues including the breast. Aromatase inhibitors block the final step in the conversion of androgen to estrogen and have been widely used in the treatment of postmenopausal women with advanced breast cancer (reviewed in [102,103]).

The current aromatase inhibitors used are the third-generation inhibitors and are much better tolerated than their nonselective predecessors. They can be divided into nonsteroidal (anastrazole and letrozole) and steroidal (exemestane) inhibitors (Fig. 4). Anastrazole was the first aromatase inhibitor to be approved for second-line treatment of advanced breast cancer in postmenopausal women; letrozole and exemestane were later found to have similar efficacy [104-107]. And recently, both anastrazole and letrozole were shown to have a higher efficacy than tamoxifen as first-line therapy for patients with advanced ER-positive tumors $[108,109]$. The efficacy of 


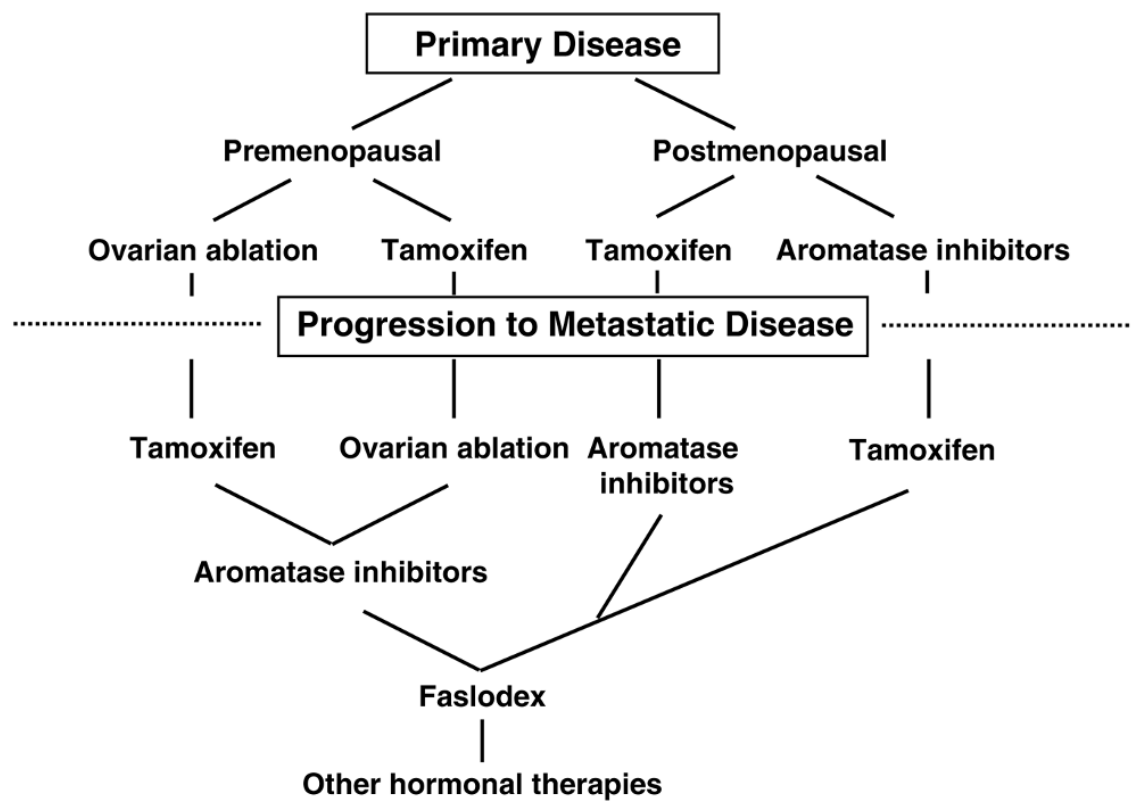

Therapy for women with ER-positive breast tumors.

aromatase inhibitors as adjuvant therapy is currently being tested in the ATAC (Arimidex, Tamoxifen, Alone or in Combination) trial [110].

\section{Tamoxifen and SERMs}

The concept of manipulating the endocrine system in the treatment of breast cancer was developed more than 100 years ago, after the first demonstration that oophorectomy could lead to regression of the disease in premenopausal women with metastatic breast cancer [111]. Subsequently, this concept has led to the development of effective and relatively safe drugs, such as tamoxifen $[112,113]$.

Tamoxifen is a first-generation non-steroidal SERM and is currently the most frequently prescribed drug for the treatment of all stages of breast cancer. Tamoxifen was approved by the Food and Drug Administration (FDA) in 1977 for the treatment of women with advanced breast cancer, in 1986 for adjuvant treatment of primary breast cancer, and later in 1990 for adjuvant therapy in premenopausal and postmenopausal women with node-negative disease (reviewed in [113,114]). For women with ER-positive breast tumors, tamoxifen results in a $50 \%$ annual reduction in the recurrence rate and a $28 \%$ annual reduction in the death rate $[115,116]$. Women with metastatic disease who have ER-positive tumors also benefit from treatment with tamoxifen [117]. In addition, findings that tamoxifen could reduce the incidence of con- trials [118]. The Breast Cancer Prevention Trial (BCRT) demonstrated that tamoxifen can be used as a preventive therapy because it reduced the incidence of ER-positive breast cancer by about $50 \%[119,120]$. The results of the International Breast Cancer Intervention Study (IBIS-1) also showed a more than 30\% reduction in the risk for breast cancer in tamoxifen-treated group compared with placebo. There was, however, a significantly higher rate of venous thromboembolic events in the tamoxifen group, raising the concern of overall risk:benefit ratio for the prophylactic use of tamoxifen [121].

The success of tamoxifen is based on a balance between its agonistic and antagonistic activities. Tamoxifen is an antagonist in the breast, whereas it has agonist effects on bone, serum lipid profile, and the cardiovascular system [122-126]. The antiestrogenic activity of tamoxifen in the breast is mediated by its competitive inhibition of estrogen binding to ER and the recruitment of corepessors rather than coactivators to target promoters [127,128]. Although the efficacy of tamoxifen in treating breast cancer has been attributed to both its cytostatic and cytotoxic effects [129-133], the critical targets remain to be defined.

A serious adverse effect of tamoxifen is an increased incidence of endometrial cancer due to its undesirable agonistic activity in the uterus [134,135]. Compelling evidence suggests that the estrogenic effect of tamoxifen is highly dependent on the tissue, the cell, and the promoter context. Work from several groups has implicated 
<smiles>CCC(C1=CCC2CCC1C2)=C(c1ccccc1)C1CCC(O)CC1</smiles>

Tamoxifen<smiles>CN(C)CCOc1ccc(C(CCCl)(c2ccccc2)c2ccccc2)cc1</smiles>

Toremifene

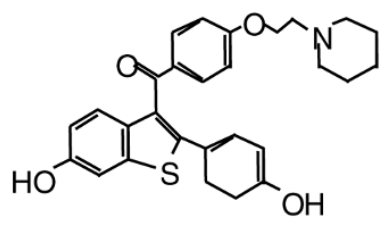

Raloxifene<smiles>CC(F)(F)CCCS(=O)(=O)CCCCCCC1CC2=C(CCC(O)C=C2)C2CCC3(C)C(O)CCC3C12</smiles>

Faslodex (Fulvestrant, ICI 182,780)<smiles>CC(C)(C)c1cc(Cn2cncn2)cc(C(C)(C)N)c1</smiles>

Anastrazole<smiles>N#Cc1ccc(C(c2ccc(C#N)cc2)(c2ccco2)n2cnnc2)cc1</smiles>

(Nonsteroidal AI)<smiles>CC1CC2C3CCC(O)C3CCC2C2CCCCC12</smiles>

Exemestane

(Steroidal Al) various coregulators as the mediators of these cell-type and promoter-specific effects. In one model, tamoxifen inhibits the activation of the ER AF-2 domain but does not inhibit AF-1 activity, allowing AF-1 to recruit coactivators such as steroid hormone receptor coactivator-1 (SRC-1) and p68 $[49,136,137]$. In contrast, the expression level of corepressors such as SMRT and N-CoR has been suggested to have a role in the antagonist activity of tamoxifen: blocking N-CoR or SMRT expression might convert tamoxifen into an agonist [138]. In mouse embryonic fibroblasts (MEFs) from N-CoR ${ }^{-1-}$ animals, tamoxifen functions as a full agonist on ER-regulated transcription, and the introduction of $\mathrm{N}-\mathrm{CoR}$ expression in these MEFs reverses this effect [139].

In addition to the level of expression, the level of corepressor binding can influence SERM effects on ER activity [64]. However, when Morrison and co-workers inhibited the $\mathrm{N}-\mathrm{CoR}$ activity by a dominant-negative $\mathrm{N}-\mathrm{CoR}$ con- struct in MCF-7 cells, the transcriptional activity of ER was not altered by treatment with tamoxifen. Correspondingly, the histone acetylation levels in the promoters of the endogenous estrogen-responsive genes were unchanged in cells expressing the dominant-negative N-CoR construct, regardless of ligand. In vitro cell proliferation and in vivo tumor growth were also unaffected in these cells. These results suggest that corepressors other than $\mathrm{N}-\mathrm{CoR}$ might be involved in the ability of tamoxifen to repress estrogen-responsive transcription and tumor growth [140]. Nevertheless, compelling evidence supports the notion that binding to selective coregulatory factors on a specific target gene promoter in a given tissue or cell type determines the agonistic/antagonistic activity of tamoxifen. In certain tissues such as the uterus, in which the AF-1 activity is more significant, the agonistic activity of tamoxifen is predominant [141]. Recent work has demonstrated that, in endometrial cancer cells, tamoxifen acts like estrogen by stimulating the recruitment of 
coactivators to the non-classical target gene promoters, and this requires a higher level of p160 coactivators [128].

The undesirable estrogenic activity of tamoxifen in the uterus has fueled the search for better SERMs. Two additional SERMs have been approved by the FDA for clinical use in the USA: toremifen for the treatment of advanced breast cancer and raloxifene for the prevention and treatment of postmenopausal osteoporosis (Fig. 4). Like tamoxifen, toremifene is a derivative of triphenylethylene and thus has very similar efficacy and side-effect profiles to those of tamoxifen, and exhibits cross-resistance with tamoxifen [142-144]. Raloxifene is a nonsteroidal benzothiophene and has a somewhat different profile of activities. When raloxifene was tested in the Multiple Outcomes Raloxifene Evaluation (MORE) trial for its effect on bone mineral density and vertebral fracture incidence in postmenopauseal women with osteoporosis, it was found to have clear benefits in decreasing the risk for vertebral fractures and in increasing bone density. Moreover, raloxifene was reported to reduce the risk for invasive breast cancer by $72 \%$ and the risk for ER-positive breast cancer by $84 \%$ [145]. This, together with the observation that raloxifene does not increase the risk for endometrial cancer, raised the question whether raloxifene would have advantages over tamoxifen as a chemopreventive agent in women at increased risk for breast cancer. The ongoing STAR (Study of Tamoxifen And Raloxifene) trial should resolve this issue [146].

In addition to a role for coregulators in determining the spectrum of SERM activity, other mechanisms are probably important (reviewed in [147-150]). For example, ER $\beta$ is expressed only in certain target tissues, and its responses to various ligands are distinct from those of ER $\alpha$ [151-153]. Thus, the biological activities of SERMs are determined by a multitude of mechanisms. It is hoped that an understanding of these mechanisms in detail will lead to the development of new SERMs with the desired clinical profile.

\section{Tamoxifen resistance}

The efficacy of tamoxifen in many patients with breast cancer is limited by a couple of factors. First, only $60-70 \%$ of the breast tumors are ER-positive, and the anti-tumor activity of tamoxifen is observed exclusively in tumors that express ER. Second, almost all patients with advanced breast cancer who initially respond to tamoxifen therapy will eventually develop resistance to the therapy. Potential genetic or epigenetic changes within the tumor that might contribute to tamoxifen resistance include the following: altered ER expression; hypersensitivity of ER to low levels of circulating estrogen due to ER mutations or variants that lead to constitutively transcriptionally active corepressors that lead to ER activation, rather than inhibition, by tamoxifen; and ligand-independent ER activity stimulated by aberrant expression of growth factors. Although loss of ER expression has been reported in a few cases of tamoxifen resistance [154], most of the acquired resistance is not due to alteration in the ER status, and many of these tumors respond to second-line endocrine therapies.

Differences in mechanisms by which tamoxifen and other endocrine therapies affect ER function might define patterns of cross-resistance between tamoxifen and the second-line therapy. Cross-resistance between triphenylethylenes, for instance tamoxifen and toremifene, has been clearly demonstrated in breast cancer patients. This is also true of tamoxifen and raloxifene. In contrast, the pure antiestrogen fulvestrant can induce responses in patients who have failed to respond to tamoxifen. Aromatase inhibitors have also produced significant responses as second-line therapies after antiestrogens.

We have reviewed above that recruitment of coactivators or corepressors to ER has a role in determining the switch between receptor activation and repression, and the coordinated action of ligand, receptor, and coregulators contributes to distinct patterns of gene expression in biological settings. Cumulative evidence suggests that intricate modulation of the receptor:coregulator ratio in distinct cells and tissues determines their response or resistance to endocrine therapy. The p160 coactivator, AIB1 (for 'amplified in breast cancer'), was identified on the basis of its frequent amplification in breast cancer [25]. Overexpression of AIB1 mRNA and protein has been revealed in more than $60 \%$ and roughly $10 \%$ of the breast tumors, respectively $[155,156]$. High levels of both AIB1 and HER-2 protein in breast tumors have been recently associated with tamoxifen resistance. A potential mechanism of this resistance involves activation of the MAPK cascade resulting from increased signaling from HER-2, which in turn activates AIB1, and the high level of AIB1mediated ER activity increases the agonistic activity of tamoxifen [157]. Conversely, low mRNA levels of the corepressor $\mathrm{N}-\mathrm{CoR}$ have been associated with resistance to tamoxifen [158]. Identifying aberrant coregulators will assist in designing future therapeutic applications to improve the efficacy of the current endocrine therapy. It remains a challenge to dissect the regulation of a specific coregulator in a given cell or tissue type in response to SERMs and to target the factors without having detrimental effects because these factors are also involved in mediating responses from a variety of signaling pathways.

Apart from hormonal therapies that directly target estrogen-ER signaling, inhibitors of growth factor activity have attracted increasing interest in the treatment of breast cancer. EGFR and ErbB-2/HER-2/neu are examples of 
growth factor signaling molecules that are being targeted for breast cancer. Overexpression of EGFR or expression of a truncated and constitutively active form of EGFR is found in some breast cancers [159-161]. More importantly, HER-2 amplification is found in about $25 \%$ of breast cancers and is correlated with poor disease-free survival and resistance to chemotherapy and endocrine therapy (reviewed in [162]).

Strategies to target EGFR and ErbB-2/HER-2/neu include antireceptor antibodies, tyrosine kinase inhibitors, ligand-toxin conjugates, and receptor antisense molecules (reviewed in [163]). The tyrosine kinase inhibitor Iressa (ZD 1839, gefitinib) was developed mainly for the treatment of advanced lung cancers but has been shown in phase I/II trials to have potential benefits in other solid tumors, including breast cancer. Treatment with Iressa can inhibit growth of breast cancer cell lines in vitro that are resistant to tamoxifen and fulvestrant. Moreover, when used concurrently with either of the antiestrogens, Iressa prevented the development of resistance [164]. Trastuzumab (Herceptin), a humanized monoclonal antibody directed against the extracellular domain of the HER-2 protein, is the first HER-2-directed therapy that has gained approval from the US FDA for the treatment of patients with metastatic breast cancer [165]. Several phase II trials have indicated that trastuzumab has synergistic or additive effects in combination with chemotherapies and hormonal agents. In vitro studies have shown that treatment with trastuzumab in HER-2-overexpressing breast cancer cells can restore cell sensitivity to both estrogen and tamoxifen [163].

\section{Other nuclear receptor-targeted therapies}

In addition to ER, progesterone receptor is targeted in the treatment of advanced receptor-positive breast cancer. However, because of their side-effect profile, progestins are in general now used as third-line or fourth-line therapy [166]. Other agents currently under development for the prevention and treatment of breast cancer include the ligands of other nuclear receptors. Retinoids, ligands for the retinoic acid receptors (RARs and RXRs), have been shown to inhibit cell proliferation in breast cancer cells [167-171]. Other nuclear receptor ligands that have been shown to exhibit inhibitory effects on breast cancer include those for PPAR $\gamma$ and VDR (vitamin D receptor) (reviewed in [172-174]). Although this is an area of active investigation, none of these compounds has yet made it to the clinic.

\section{Conclusions and future perspectives}

The ER signaling hierarchy is far from isolated from other cellular signaling cascades. It integrates multiple signals from both hormonal ligands and other extracellular and intracellular stimuli in coordination with an array of cofactor complexes, and regulates both physiological and pathological processes. The clinical limitation of the firstgeneration SERM, tamoxifen, has fueled an intense search for newer and better SERMs. The ultimate goal of the SERM research is to find a molecule that has all the benefits of estrogen, none of its adverse effects, and offers protection against breast cancer. To achieve this goal, a better understanding is needed of how the orchestrated action of SERM, receptor, and coregulators contribute to distinct patterns of gene expression. Multiple studies have supported the hypothesis that intricate modulation of the receptor-coregulator interaction on a specific target gene promoter in a given tissue, cell, or tumor context can dictate the degree and direction of SERM action.

Dissecting the interrelationship between ER and its coregulators may open the door for the rational design of novel therapeutics. The cellular dynamics of these cofactor complexes are beginning to be elucidated with assays such as chromatin immunoprecipitation (ChIP) and real-time imaging techniques. An understanding of how the program of ER-regulated transcription is dysregulated in breast cancer and how it changes with the development of resistance to endocrine therapy will lead to improved strategies for the use of existing endocrine therapies and for the development of new and more effective agents for the prevention and treatment of breast cancer.

\section{Competing interests}

MB receives sponsored research support and consulting fees from Novartis Pharmaceuticals.

\section{References}

1. Mangelsdorf DJ, Thummel C, Beato M, Herrlich P, Schutz G, Umesono K, Blumberg B, Kastner P, Mark M, Chambon P, Evans $\mathrm{RM}$ : The nuclear receptor superfamily: the second decade. Cell 1995, 83:835-839.

2. Sommer S, Fuqua SA: Estrogen receptor and breast cancer. Semin Cancer Biol 2001, 11:339-352.

3. Turner RT, Riggs BL, Spelsberg TC: Skeletal effects of estrogen. Endocr Rev 1994, 15:275-300.

4. Farhat MY, Lavigne MC, Ramwell PW: The vascular protective effects of estrogen. FASEB J 1996, 10:615-624.

5. Beato M, Herrlich P, Schutz G: Steroid hormone receptors: many actors in search of a plot. [Review]. Cell 1995, 83:851857.

6. Green S, Walter P, Greene G, Krust A, Goffin C, Jensen E, Scrace G, Waterfield M, Chambon P: Cloning of the human oestrogen receptor cDNA. J Steroid Biochem 1986, 24:77-83.

7. Kuiper GG, Enmark E, Pelto-Huikko M, Nilsson S, Gustafsson JA: Cloning of a novel receptor expressed in rat prostate and ovary. Proc Natl Acad Sci USA 1996, 93:5925-5930.

8. Mosselman S, Polman J, Dijkema R: ER beta: identification and characterization of a novel human estrogen receptor. FEBS Lett 1996, 392:49-53.

9. Kumar V, Green S, Stack G, Berry M, Jin J-R, Chambon P: Functional domains of the human estrogen receptor. Cell 1987, 51: 941-951.

10. Klinge CM: Estrogen receptor interaction with estrogen response elements. Nucleic Acids Res 2001, 29:2905-2919.

11. Glass CK: Differential recognition of target genes by nuclear receptor monomers, dimers, and heterodimers. Endocr Rev 1994, 15:391-407.

12. Aumais JP, Lee HS, DeGannes C, Horsford J, White JH: Function of directly repeated half-sites as response elements for steroid hormone receptors. J Biol Chem 1996, 271:12568-12577. 
13. Kushner PJ, Agard DA, Greene GL, Scanlan TS, Shiau AK, Uht RM, Webb P: Estrogen receptor pathways to AP-1. J Steroid Biochem Mol Biol 2000, 74:311-317.

14. Kushner PJ, Agard D, Feng WJ, Lopez G, Schiau A, Uht R, Webb $P$, Greene $G$ : Oestrogen receptor function at classical and alternative response elements. Novartis Found Symp 2000, 230:20-26; discussion 27-40.

15. Hall JM, Couse JF, Korach KS: The multifaceted mechanisms of estradiol and estrogen receptor signaling. J Biol Chem 2001, 276:36869-36872

16. Rosenfeld MG, Glass CK: Coregulator codes of transcriptional regulation by nuclear receptors. J Biol Chem 2001, 276: 36865-36868.

17. Kingston RE, Narlikar GJ: ATP-dependent remodeling and acetylation as regulators of chromatin fluidity. Genes Dev 1999, 13:2339-2352.

18. DiRenzo J, Shang Y, Phelan M, Sif S, Myers M, Kingston R, Brown $\mathrm{M}$ : BRG-1 is recruited to estrogen-responsive promoters and cooperates with factors involved in histone acetylation. $\mathrm{Mol}$ Cell Biol 2000, 20:7541-7549.

19. Ogryzko VV, Schiltz RL, Russanova V, Howard BH, Nakatani Y: The transcriptional coactivators p300 and CBP are histone acetyltransferases. Cell 1996, 87:953-959.

20. Ogryzko VV, Kotani T, Zhang X, Schlitz RL, Howard T, Yang XJ, Howard $\mathrm{BH}$, Qin J, Nakatani Y: Histone-like TAFs within the PCAF histone acetylase complex. Cell 1998, 94:35-44.

21. Yang XJ, Ogryzko VV, Nishikawa J, Howard BH, Nakatani Y: A p300/CBP-associated factor that competes with the adenoviral oncoprotein E1A. Nature 1996, 382:319-324.

22. Onate SA, Tsai SY, Tsai MJ, O'Malley BW: Sequence and characterization of a coactivator for the steroid hormone receptor superfamily. Science 1995, 270:1354-1357.

23. Hong H, Kohli K, Garabedian MJ, Stallcup M: GRIP1, a transcriptional coactivator for the AF-2 transactivation domain of steroid, thyroid, retinoid, and vitamin $\mathrm{D}$ receptors. $\mathrm{Mol} \mathrm{Cell}$ Biol 1997, 17:2735-2744.

24. Voegel JJ, Heine MJ, Zechel C, Chambon P, Gronemeyer H: TIF2, a $160 \mathrm{kDa}$ transcriptional mediator for the ligand-dependent activation function AF-2 of nuclear receptors. EMBO J 1996, 15:3667-3675

25. Anzick SL, Kononen J, Walker RL, Azorsa DO, Tanner MM, Guan XY, Sauter G, Kallioniemi OP, Trent JM, Meltzer PS: AIB1, a steroid receptor coactivator amplified in breast and ovarian cancer. Science 1997, 277:965-968.

26. Chen H, Lin RJ, Schiltz RL, Chakravarti D, Nash A, Nagy L, Privalsky ML, Nakatani Y, Evans RM: Nuclear receptor coactivator ACTR is a novel histone acetyltransferase and forms a multimeric activation complex with P/CAF and CBP/p300. Cell 1997, 90:569-580.

27. Li H, Gomes PJ, Chen JD: RAC3, a steroid/nuclear receptorassociated coactivator that is related to SRC-1 and TIF2. Proc Natl Acad Sci USA 1997, 94:8479-8484.

28. Suen CS, Berrodin TJ, Mastroeni R, Cheskis BJ, Lyttle CR, Frail $\mathrm{DE}$ : A transcriptional coactivator, steroid receptor coactivator3 , selectively augments steroid receptor transcriptional activity. J Biol Chem 1998, 273:27645-27653.

29. Takeshita A, Cardona GR, Koibuchi N, Suen CS, Chin WW: TRAM-1, A novel 160-kDa thyroid hormone receptor activator molecule, exhibits distinct properties from steroid receptor coactivator-1. J Biol Chem 1997, 272:27629-27634.

30. Torchia J, Rose DW, Inostroza J, Kamei Y, Westin S, Glass CK, Rosenfeld MG: The transcriptional co-activator p/CIP binds CBP and mediates nuclear-receptor function. Nature 1997, 387:677-684.

31. Heery DM, Kalkhoven E, Hoare S, Parker MG: A signature motif in transcriptional co-activators mediates binding to nuclear receptors. Nature 1997, 387:733-736.

32. Chen D, Huang SM, Stallcup MR: Synergistic $p 160$ coactivatordependent enhancement of estrogen receptor function by CARM1 and p300. J Biol Chem 2000, 275:40810-40816.

33. Misiti S, Schomburg L, Yen PM, Chin WW: Expression and hormonal regulation of coactivator and corepressor genes. Endocrinology 1998, 139:2493-2500.

34. Wang Z, Rose DW, Hermanson O, Liu F, Herman T, Wu W, Szeto D, Gleiberman A, Krones A, Pratt K, Rosenfeld R, Glass CK, Rosenfeld MG: Regulation of somatic growth by the $\mathrm{p} 160$ coactivator p/CIP. Proc Natl Acad Sci USA 2000, 97:13549-13554.
35. Lauritsen KJ, List HJ, Reiter R, Wellstein A, Riegel AT: A role for TGF- $\beta$ in estrogen and retinoid mediated regulation of the nuclear receptor coactivator AIB1 in MCF-7 breast cancer cells. Oncogene 2002, 21:7147-7155.

36. Xu J, Qiu Y, DeMayo FJ, Tsai SY, Tsai MJ, O'Malley BW: Partial hormone resistance in mice with disruption of the steroid receptor coactivator-1 (SRC-1) gene. Science 1998, 279:19221925.

37. Nishihara E, Yoshida-Komiya H, Chan CS, Liao L, Davis RL, O'Malley BW, Xu J: SRC-1 null mice exhibit moderate motor dysfunction and delayed development of cerebellar Purkinje cells. J Neurosci 2003, 23:213-222.

38. Xu J, Liao L, Ning G, Yoshida-Komiya H, Deng C, O'Malley BW: The steroid receptor coactivator SRC-3 (p/CIP/RAC3/AIB1/ ACTR/TRAM-1) is required for normal growth, puberty, female reproductive function, and mammary gland development. Proc Natl Acad Sci USA 2000, 97:6379-6384.

39. Burakov D, Wong CW, Rachez C, Cheskis BJ, Freedman LP: Functional interactions between the estrogen receptor and DRIP205, a subunit of the heteromeric DRIP coactivator complex. J Biol Chem 2000, 275:20928-20934.

40. Kang YK, Guermah M, Yuan CX, Roeder RG: The TRAP/Mediator coactivator complex interacts directly with estrogen receptors alpha and beta through the TRAP220 subunit and directly enhances estrogen receptor function in vitro. Proc Natl Acad Sci USA 2002, 99:2642-2647.

41. Warnmark A, Almlof T, Leers J, Gustafsson JA, Treuter E: Differential recruitment of the mammalian mediator subunit TRAP220 by estrogen receptors ER $\alpha$ and ER $\beta$. J Biol Chem 2001, 276:23397-23404.

42. Puigserver P, Wu Z, Park CW, Graves R, Wright M, Spiegelman BM: A cold-inducible coactivator of nuclear receptors linked to adaptive thermogenesis. Cell 1998, 92:829-839.

43. Tcherepanova I, Puigserver P, Norris JD, Spiegelman BM, McDonnell DP: Modulation of estrogen receptor- $\alpha$ transcriptional activity by the coactivator PGC-1. J Biol Chem 2000, 275: 16302-16308

44. Saville B, Poukka H, Wormke M, Janne OA, Palvimo JJ, Stoner M, Samudio I, Safe S: Cooperative coactivation of estrogen receptor $\alpha$ in ZR-75 human breast cancer cells by SNURF and TATA-binding protein. J Biol Chem 2002, 277:2485-2497.

45. Vadlamudi RK, Wang RA, Mazumdar A, Kim Y, Shin J, Sahin A, Kumar R: Molecular cloning and characterization of PELP1, a novel human coregulator of estrogen receptor alpha. $J \mathrm{Biol}$ Chem 2001, 276:38272-38279.

46. Shao W, Halachmi S, Brown M: ERAP140, a conserved tissuespecific nuclear receptor coactivator. Mol Cell Biol 2002, 22: 3358-3372.

47. Chang C, Norris JD, Gron H, Paige LA, Hamilton PT, Kenan DJ, Fowlkes D, McDonnell DP: Dissection of the LXXLL nuclear receptor-coactivator interaction motif using combinatorial peptide libraries: discovery of peptide antagonists of estrogen receptors $\alpha$ and $\beta$. Mol Cell Biol 1999, 19:8226-8239.

48. Lanz RB, McKenna NJ, Onate SA, Albrecht U, Wong J, Tsai SY, Tsai MJ, O'Malley BW: A steroid receptor coactivator, SRA, functions as an RNA and is present in an SRC-1 complex. Cell 1999, 97:17-27.

49. Endoh H, Maruyama K, Masuhiro $Y$, Kobayashi $Y$, Goto M, Tai H, Yanagisawa J, Metzger D, Hashimoto S, Kato S: Purification and identification of p68 RNA helicase acting as a transcriptional coactivator specific for the activation function 1 of human estrogen receptor $\alpha$. Mol Cell Biol 1999, 19:5363-5372.

50. Watanabe M, Yanagisawa J, Kitagawa H, Takeyama K, Ogawa S, Arao Y, Suzawa M, Kobayashi Y, Yano T, Yoshikawa H, Masuhiro $Y$, Kato S: A subfamily of RNA-binding DEAD-box proteins acts as an estrogen receptor $\alpha$ coactivator through the $\mathrm{N}$-terminal activation domain (AF-1) with an RNA coactivator, SRA. EMBO J 2001, 20:1341-1352.

51. Ko L, Cardona GR, Henrion-Caude A, Chin WW: Identification and characterization of a tissue-specific coactivator, GT198, that interacts with the DNA-binding domains of nuclear receptors. Mol Cell Biol 2002, 22:357-369.

52. Zwijsen RM, Wientjens E, Klompmaker R, van der Sman J, Bernards R, Michalides RJ: CDK-independent activation of estrogen receptor by cyclin D1. Cell 1997, 88:405-415.

53. Neuman E, Ladha MH, Lin N, Upton TM, Miller SJ, DiRenzo J, Pestell RG, Hinds PW, Dowdy SF, Brown M, Ewen ME: Cyclin 
D1 stimulation of estrogen receptor transcriptional activity independent of cdk4. Mol Cell Biol 1997, 17:5338-5347.

54. McMahon C, Suthiphongchai T, DiRenzo J, Ewen ME: P/CAF associates with cyclin D1 and potentiates its activation of the estrogen receptor. Proc Natl Acad Sci USA 1999, 96:53825387.

55. Lamb J, Ladha MH, McMahon C, Sutherland RL, Ewen ME: Regulation of the functional interaction between cyclin D1 and the estrogen receptor. Mol Cell Biol 2000, 20:8667-8675.

56. Li Z, Joyal JL, Sacks DB: Calmodulin enhances the stability of the estrogen receptor. J Biol Chem 2001, 276:17354-17360.

57. Fan M, Long X, Bailey JA, Reed CA, Osborne E, Gize EA, Kirk EA, Bigsby RM, Nephew KP: The activating enzyme of NEDD8 inhibits steroid receptor function. Mol Endocrinol 2002, 16: 315-330.

58. Matsuda T, Yamamoto T, Muraguchi A, Saatcioglu F: Cross-talk between transforming growth factor- $\beta$ and estrogen receptor signaling through Smad3. J Biol Chem 2001, 276:4290842914.

59. Wong CW, McNally C, Nickbarg E, Komm BS, Cheskis BJ: Estrogen receptor-interacting protein that modulates its nongenomic activity-crosstalk with Src/Erk phosphorylation cascade. Proc Natl Acad Sci USA 2002, 99:14783-14788.

60. Chen JD, Evans RM: A transcriptional co-repressor that interacts with nuclear hormone receptors. Nature 1995, 377:454457.

61. Horlein AJ, Naar AM, Heinzel T, Torchia J, Gloss B, Kurokawa R, Ryan A, Kamei Y, Soderstrom M, Glass CK, Rosenfeld MG: Ligand-independent repression by the thyroid hormone receptor mediated by a nuclear receptor co-repressor. Nature 1995, 377:397-404.

62. Shang Y, Hu X, DiRenzo J, Lazar MA, Brown M: Cofactor dynamics and sufficiency in estrogen receptor-regulated transcription. Cell 2000, 103:843-852.

63. Huang $\mathrm{HJ}$, Norris JD, McDonnell DP: Identification of a negative regulatory surface within estrogen receptor $\alpha$ provides evidence in support of a role for corepressors in regulating cellular responses to agonists and antagonists. Mol Endocrinol 2002, 16:1778-1792.

64. Webb P, Nguyen P, Kushner PJ: Differential SERM effects on corepressor binding dictate ER $\alpha$ activity in vivo. $J \mathrm{Biol}$ Chem 2003, 278:6912-6920.

65. Wei LN, Hu X, Chandra D, Seto E, Farooqui M: Receptor-interacting protein 140 directly recruits histone deacetylases for gene silencing. J Biol Chem 2000, 275:40782-40787.

66. Oesterreich S, Zhang Q, Hopp T, Fuqua SA, Michaelis M, Zhao $\mathrm{HH}$, Davie JR, Osborne CK, Lee AV: Tamoxifen-bound estrogen receptor (ER) strongly interacts with the nuclear matrix protein HET/SAF-B, a novel inhibitor of ER-mediated transactivation. Mol Endocrinol 2000, 14:369-381.

67. Johansson L, Thomsen JS, Damdimopoulos AE, Spyrou G, Gustafsson JA, Treuter E: The orphan nuclear receptor SHP inhibits agonist-dependent transcriptional activity of estrogen receptors ER $\alpha$ and ERß. J Biol Chem 1999, 274:345-353.

68. Montano MM, Ekena K, Delage-Mourroux R, Chang W, Martini P, Katzenellenbogen BS: An estrogen receptor-selective coregulator that potentiates the effectiveness of antiestrogens and represses the activity of estrogens. Proc Natl Acad Sci USA 1999, 96:6947-6952.

69. Zhang H, Thomsen JS, Johansson L, Gustafsson JA, Treuter E: DAX-1 functions as an LXXLL-containing corepressor for activated estrogen receptors. J Biol Chem 2000, 275:3985539859 .

70. Moras $\mathrm{D}$, Gronemeyer $\mathrm{H}$ : The nuclear receptor ligand-binding domain: structure and function. Curr Opin Cell Biol 1998, 10: 384-391.

71. Brzozowski AM, Pike AC, Dauter Z, Hubbard RE, Bonn T, Engstrom O, Ohman L, Greene GL, Gustafsson JA, Carlquist M: Molecular basis of agonism and antagonism in the oestrogen receptor. Nature 1997, 389:753-758.

72. Shiau AK, Barstad D, Loria PM, Cheng L, Kushner PJ, Agard DA, Greene GL: The structural basis of estrogen receptor/coactivator recognition and the antagonism of this interaction by tamoxifen. Cell 1998, 95:927-937.

73. Pike AC, Brzozowski AM, Hubbard RE, Bonn T, Thorsell AG, Engstrom O, Ljunggren J, Gustafsson JA, Carlquist M: Structure of the ligand-binding domain of oestrogen receptor beta in the presence of a partial agonist and a full antagonist. $E M B O$ $J$ 1999, 18:4608-4618.

74. Pike AC, Brzozowski AM, Walton J, Hubbard RE, Thorsell AG, Li YL, Gustafsson JA, Carlquist M: Structural insights into the mode of action of a pure antiestrogen. Structure (Camb) 2001, 9:145-153.

75. Danielian PS, White R, Lees JA, Parker MG: Identification of a conserved region required for hormone dependent transcriptional activation by steroid hormone receptors. EMBO J 1992, 11:1025-1033.

76. Darimont BD, Wagner RL, Apriletti JW, Stallcup MR, Kushner PJ, Baxter JD, Fletterick RJ, Yamamoto KR: Structure and specificity of nuclear receptor-coactivator interactions. Genes Dev 1998, 12:3343-3356.

77. Smith CL: Cross-talk between peptide growth factor and estrogen receptor signaling pathways. Biol Reprod 1998, 58: 627-632.

78. Segars $\mathrm{JH}$, Driggers $\mathrm{PH}$ : Estrogen action and cytoplasmic signaling cascades. Part I: membrane-associated signaling complexes. Trends Endocrinol Metab 2002, 13:349-354

79. Driggers $\mathrm{PH}$, Segars $\mathrm{JH}$ : Estrogen action and cytoplasmic signaling pathways. Part II: the role of growth factors and phosphorylation in estrogen signaling. Trends Endocrinol Metab 2002, 13:422-427.

80. Kato $\mathrm{S}$, Endoh $\mathrm{H}$, Masuhiro $\mathrm{Y}$, Kitamoto $\mathrm{T}$, Uchiyama S, Sasaki $\mathrm{H}$, Masushige S, Gotoh Y, Nishida E, Kawashima H, Metzger D Chambon P: Activation of the estrogen receptor through phosphorylation by mitogen-activated protein kinase. Science 1995, 270:1491-1494.

81. Bunone G, Briand P-A, Miksicek RJ, Picard D: Activation of the unliganded estrogen receptor by EGF involves the MAP kinase pathway and direct phosphorylation. EMBO J. 1996, 15:2174-2183.

82. Joel PB, Traish AM, Lannigan DA: Estradiol-induced phosphorylation of serine 118 in the estrogen receptor is independent of p42/p44 mitogen-activated protein kinase. J Biol Chem 1998, 273:13317-13323.

83. Chen D, Riedl T, Washbrook E, Pace PE, Coombes RC, Egly JM, Ali: Activation of estrogen receptor alpha by $\mathbf{S} 118$ phosphorylation involves a ligand-dependent interaction with TFIIH and participation of CDK7. Mol Cell 2000, 6:127-137.

84. Aronica SM, Katzenellenbogen BS: Stimulation of estrogen receptor-mediated transcription and alteration in the phosphorylation state of the rat uterine estrogen receptor by estrogen, cyclic adenosine monophosphate, and insulin-like growth factor-I. Mol Endocrinol 1993, 7:743-752.

85. Cho $\mathrm{H}$, Aronica SM, Katzenellenbogen BS: Regulation of progesterone receptor gene expression in MCF-7 breast cance cells: a comparison of the effects of cyclic adenosine $3^{\prime}, 5^{\prime}$ monophosphate, estradiol, insulin-like growth factor-l, and serum factors. Endocrinology 1994, 134:658-664.

86. Chen D, Pace PE, Coombes RC, Ali S: Phosphorylation of human estrogen receptor $\alpha$ by protein kinase $A$ regulates dimerization. Mol Cell Biol 1999, 19:1002-1015.

87. Rowan BG, Weigel NL, O'Malley BW: Phosphorylation of steroid receptor coactivator-1. Identification of the phosphorylation sites and phosphorylation through the mitogen-activated protein kinase pathway. J Biol Chem 2000, 275: 4475-4483.

88. Font de Mora J, Brown M: AIB1 is a conduit for kinase-mediated growth factor signaling to the estrogen receptor. Mol Cell Biol 2000, 20:5041-5047.

89. Janknecht $R$, Nordheim A: MAP kinase-dependent transcriptional coactivation by Elk-1 and its cofactor CBP. Biochem Biophys Res Commun 1996, 228:831-837.

90. Liu YZ, Chrivia JC, Latchman DS: Nerve growth factor up-regulates the transcriptional activity of CBP through activation of the p42/p44(MAPK) cascade. J Biol Chem 1998, 273:32400-32407.

91. Gusterson R, Brar B, Faulkes D, Giordano A, Chrivia J, Latchman $D$ : The transcriptional co-activators CBP and $\mathrm{p} 300$ are activated via phenylephrine through the p42/p44 MAPK cascade. $J$ Biol Chem 2002, 277:2517-2524.

92. Ait-Si-Ali S, Carlisi D, Ramirez S, Upegui-Gonzalez LC, Duquet A, Robin P, Rudkin B, Harel-Bellan A, Trouche D: Phosphorylation by p44 MAP kinase/ERK1 stimulates CBP histone acetyl transferase activity in vitro. Biochem Biophys Res Commun 1999, 262:157-162. 
93. Redeuilh G, Attia A, Mester J, Sabbah MP: Transcriptional activation by the oestrogen receptor $\alpha$ is modulated through inhibition of cyclin-dependent kinases. Oncogene 2002, 21:5773-5782.

94. Simoncini T, Hafezi-Moghadam A, Brazil DP, Ley K, Chin WW, Liao JK: Interaction of oestrogen receptor with the regulatory subunit of phosphatidylinositol-3-OH kinase. Nature 2000, 407:538-541.

95. Kousteni S, Bellido T, Plotkin LI, O'Brien CA, Bodenner DL, Han L, Han K, DiGregorio GB, Katzenellenbogen JA, Katzenellenbogen BS, Roberson PK, Weinstein RS, Jilka RL, Manolagas SC: Nongenotropic, sex-nonspecific signaling through the estrogen or androgen receptors: dissociation from transcriptional activity. Cell 2001, 104:719-730.

96. Jensen EV, Jacobson, HI: Basic guides to the mechanism of estrogen action. Recent Prog Horm Res 1962, 18:387-414.

97. Speirs V: Oestrogen receptor $\beta$ in breast cancer: good, bad or still too early to tell? J Patho/ 2002, 197:143-147.

98. Clarke RB, Howell A, Potten CS, Anderson, E: Dissociation between steroid receptor expression and cell proliferation in the human breast. Cancer Res 1997, 57:4987-4991.

99. Fuqua SA: The role of estrogen receptors in breast cancer metastasis. J Mammary Gland Biol Neoplasia 2001, 6:407-417.

100. Ingle JN, Krook JE, Green SJ, Kubista TP, Everson LK, Ahmann DL, Chang MN, Bisel HF, Windschitl HE, Twito DI: Randomized trial of bilateral oophorectomy versus tamoxifen in premenopausal women with metastatic breast cancer. $J$ Clin Oncol 1986, 4:178-185.

101. Buchanan RB, Blamey RW, Durrant KR, Howell A, Paterson AG, Preece $P E$, Smith DC, Williams CJ, Wilson RG: A randomized comparison of tamoxifen with surgical oophorectomy in premenopausal patients with advanced breast cancer. J Clin Oncol 1986, 4:1326-1330.

102. Buzdar A: An overview of the use of non-steroidal aromatase inhibitors in the treatment of breast cancer. Eur J Cancer 2000, 36 Suppl 4:S82-S84.

103. Buzdar AU: New generation aromatase inhibitors - from the advanced to the adjuvant setting. Breast Cancer Res Treat 2002, 75 Suppl 1:S13-S17; discussion S33-S35.

104. Buzdar AU, Jonat W, Howell A, Jones SE, Blomqvist CP, Vogel CL, Eiermann W, Wolter JM, Steinberg M, Webster A, Lee D: Anastrozole versus megestrol acetate in the treatment of postmenopausal women with advanced breast carcinoma: results of a survival update based on a combined analysis of data from two mature phase III trials. Arimidex Study Group. Cancer 1998, 83:1142-1152.

105. Dombernowsky P, Smith I, Falkson G, Leonard R, Panasci L, Bellmunt J, Bezwoda W, Gardin G, Gudgeon A, Morgan M, Fornasiero A, Hoffmann W, Michel J, Hatschek T, Tjabbes T, Chaudri HA, Hornberger U, Trunet PF: Letrozole, a new oral aromatase inhibitor for advanced breast cancer: double-blind randomized trial showing a dose effect and improved efficacy and tolerability compared with megestrol acetate. J Clin Oncol 1998, 16:453-461.

106. Kaufmann M, Bajetta E, Dirix LY, Fein LE, Jones SE, Zilembo N, Dugardyn JL, Nasurdi C, Mennel RG, Cervek J, Fowst C, Polli A, Salle E, Arkhipov A, Piscitelli G, Miller LL, Massimini G: Exemestane improves survival in metastatic breast cancer: results of a phase III randomized study. Clin Breast Cancer 2000, 1 Suppl 1:S15-S18.

107. Buzdar A, Douma J, Davidson N, Elledge R, Morgan M, Smith R, Porter L, Nabholtz J, Xiang X, Brady C: Phase III, multicenter, double-blind, randomized study of letrozole, an aromatase inhibitor, for advanced breast cancer versus megestrol acetate. J Clin Oncol 2001, 19:3357-3366.

108. Bonneterre J, Buzdar A, Nabholtz JM, Robertson JF, Thurlimann B, von Euler M, Sahmoud T, Webster A, Steinberg M: Anastrozole is superior to tamoxifen as first-line therapy in hormone receptor positive advanced breast carcinoma. Cancer 2001, 92:2247-2258

109. Mouridsen $H$, Gershanovich $M$, Sun $Y$, Perez-Carrion R, Boni $C$, Monnier A, Apffelstaedt J, Smith R, Sleeboom HP, Janicke F, Pluzanska A, Dank M, Becquart D, Bapsy PP, Salminen E, Snyder R, Lassus M, Verbeek JA, Staffler B, Chaudri-Ross HA, Dugan M: Superior efficacy of letrozole versus tamoxifen as first-line therapy for postmenopausal women with advanced breast cancer: results of a phase III study of the International Letrozole Breast Cancer Group. J Clin Oncol 2001, 19:2596-2606.
110. Baum M, Budzar AU, Cuzick J, Forbes J, Houghton JH, Klijn JG, Sahmoud T, ATAC Trialists' Group: Anastrozole alone or in combination with tamoxifen versus tamoxifen alone for adjuvant treatment of postmenopausal women with early breast cancer: first results of the ATAC randomised trial. Lancet 2002, 359:2131-2139.

111. Beatson GT: On the treatment of inoperable cases of carcinoma of the mamma: suggestions for a new method of treatment with illustrative cases. Lancet 1896, 2:104-107.

112. Early Breast Cancer Trialists' Collaborative Group: Tamoxifen for early breast cancer: an overview of the randomised trials. Lancet 1998, 351:1451-1467.

113. Osborne CK: Tamoxifen in the treatment of breast cancer. $N$ Engl J Med 1998, 339:1609-1618.

114. Wickerham L: Tamoxifen - an update on current data and where it can now be used. Breast Cancer Res Treat 2002, 75 Suppl 1:S7-S12; discussion S33-S35.

115. Group EBCTC. Systemic treatment of early breast cancer by hormonal, cytotoxic, or immune therapy. 133 randomised trials involving 31,000 recurrences and 24,000 deaths among 75,000 women. Part 1. Lancet 1992, 339:1-15.

116. Group EBCTC. Systemic treatment of early breast cancer by hormonal, cytotoxic, or immune therapy. 133 randomised trials involving 31,000 recurrences and 24,000 deaths among 75,000 women. Part 2. Lancet 1992, 339:71-85.

117. Rusthoven JJ: The evidence for tamoxifen and chemotherapy as treatment for metastatic melanoma. Eur J Cancer 1998, 34 Suppl 3:S31-S36.

118. Fornander T, Cedermark B, Mattsson A, Skoog L, Theve T, Askergren J, Rutgvist LE, Glass U, Silfversward C, Somell A, Wilking N, Hjalmar ML: Adjuvant tamoxifen in early breast cancer: occurrence of new primary cancers. Lancet 1989, 333:117-120.

119. Fisher B, Costantino JP, Wickerham DL, Redmond CK, Kavanah M, Cronin WM, Vogel V, Robidoux A, Dimitrov N, Atkins J, Daly M, Wieand S, Tan-Chiu E, Ford L, Wolmark N: Tamoxifen for prevention of breast cancer: report of the National Surgical Adjuvant Breast and Bowel Project P-1 Study. J Natl Cancer Inst 1998, 90:1371-1388.

120. Wolmark N, Dunn BK: The role of tamoxifen in breast cancer prevention: issues sparked by the NSABP Breast Cancer Prevention Trial (P-1). Ann N Y Acad Sci 2001, 949:99-108.

121. Cuzick J, Forbes J, Edwards R, Baum M, Cawthorn S, Coates A, Hamed A, Howell A, Powles T; IBIS investigators: First results from the International Breast Cancer Intervention Study (IBISI): a randomised prevention trial. Lancet 2002, 360:817-824.

122. Kristensen B, Ejlertsen B, Dalgaard P, Larsen L, Holmegaard SN, Transbol I, Mouridsen HT: Tamoxifen and bone metabolism in postmenopausal low-risk breast cancer patients: a randomized study. J Clin Oncol 1994, 12:992-997.

123. Grey AB, Stapleton JP, Evans MC, Reid IR: The effect of the anti-estrogen tamoxifen on cardiovascular risk factors in normal postmenopausal women. J Clin Endocrinol Metab 1995, 80:3191-3195.

124. Grey AB, Stapleton JP, Evans MC, Tatnell MA, Ames RW, Reid IR: The effect of the antiestrogen tamoxifen on bone mineral density in normal late postmenopausal women. Am J Med 1995, 99:636-641.

125. Love RR, Wiebe DA, Feyzi JM, Newcomb PA, Chappell RJ: Effects of tamoxifen on cardiovascular risk factors in postmenopausal women after 5 years of treatment. $J$ Natl Cancer Inst 1994, 86:1534-1539.

126. Saarto T, Blomqvist C, Ehnholm C, Taskinen MR, Elomaa I: Antiatherogenic effects of adjuvant antiestrogens: a randomized trial comparing the effects of tamoxifen and toremifene on plasma lipid levels in postmenopausal women with nodepositive breast cancer. J Clin Oncol 1996, 14:429-433.

127. Jordan VC, Dowse LJ: Tamoxifen as an anti-tumour agent: effect on oestrogen binding. J Endocrinol 1976, 68:297-303.

128. Shang $Y$, Brown M: Molecular determinants for the tissue specificity of SERMs. Science 2002, 295:2465-2468.

129. Perry RR, Kang Y, Greaves B: Effects of tamoxifen on growth and apoptosis of estrogen-dependent and -independent human breast cancer cells. Ann Surg Oncol 1995, 2:238245.

130. Gelmann EP: Tamoxifen induction of apoptosis in estrogen receptor-negative cancers: new tricks for an old dog? J Nat/ Cancer Inst 1996, 88:224-226. 
131. Cameron DA, Ritchie AA, Langdon S, Anderson TJ, Miller WR: Tamoxifen induced apoptosis in ZR-75 breast cancer xenografts antedates tumour regression. Breast Cancer Res Treat 1997, 45:99-107.

132. Budtz PE: Role of proliferation and apoptosis in net growth rates of human breast cancer cells (MCF-7) treated with oestradiol and/or tamoxifen. Cell Prolif 1999, 32:289-302.

133. Cameron DA, Keen JC, Dixon JM, Bellamy C, Hanby A, Anderson TJ, Miller WR: Effective tamoxifen therapy of breast cancer involves both antiproliferative and pro-apoptotic changes. Eur $J$ Cancer 2000, 36:845-851.

134. Fisher B, Costantino JP, Redmond CK, Fisher ER, Wickerham DL, Cronin WM: Endometrial cancer in tamoxifen-treated breast cancer patients: findings from the National Surgical Adjuvant Breast and Bowel Project (NSABP) B-14. J Natl Cancer Inst 1994, 86:527-537.

135. Assikis VJ, Jordan VC: Gynecologic effects of tamoxifen and the association with endometrial carcinoma. Int J Gynaecol Obstet 1995, 49:241-257

136. Smith CL, Nawaz Z, O'Malley BW: Coactivator and corepressor regulation of the agonist/antagonist activity of the mixed antiestrogen, 4-hydroxytamoxifen. Mol Endocrinol 1997, 11: 657-666.

137. Webb P, Nguyen $P$, Shinsako J, Anderson C, Feng W, Nguyen MP, Chen D, Huang SM, Subramanian S, McKinerney E, Katzenellenbogen BS, Stallcup MR, Kushner PJ: Estrogen receptor activation function 1 works by binding $\mathrm{p} 160$ coactivator proteins. Mol Endocrinol 1998, 12:1605-1618.

138. Lavinsky RM, Jepsen K, Heinzel T, Torchia J, Mullen TM, Schiff R, Del-Rio AL, Ricote M, Ngo S, Gemsch J, Hilsenbeck SG, Osborne CK, Glass CK, Rosenfeld MG, Rose DW: Diverse signaling pathways modulate nuclear receptor recruitment of $\mathrm{N}$ CoR and SMRT complexes. Proc Natl Acad Sci USA 1998, 95: 2920-2925.

139. Jepsen K, Hermanson O, Onami TM, Gleiberman AS, Lunyak V, McEvilly RJ, Kurokawa R, Kumar V, Liu F, Seto E, Hedrick SM, Mandel G, Glass CK, Rose DW, Rosenfeld MG: Combinatorial roles of the nuclear receptor corepressor in transcription and development. Cell 2000, 102:753-763.

140. Morrison AJ, Herrera RE, Heinsohn EC, Schiff R, Osborne CK: Dominant-negative nuclear receptor corepressor relieves transcriptional inhibition of retinoic acid receptor but does not alter the agonist/antagonist activities of the tamoxifen-bound estrogen receptor. Mol Endocrino/ 2003, 17:1543-1554.

141. Sakamoto T, Eguchi H, Omoto $\mathrm{Y}$, Ayabe T, Mori H, Hayashi S: Estrogen receptor-mediated effects of tamoxifen on human endometrial cancer cells. Mol Cell Endocrinol 2002, 192:93104.

142. Curtis MG: Comparative tolerability of first-generation selective estrogen receptor modulators in breast cancer treatment and prevention. Drug Saf 2001, 24:1039-1053.

143. Pukkala E, Kyyronen P, Sankila R, Holli K: Tamoxifen and toremifene treatment of breast cancer and risk of subsequent endometrial cancer: a population-based case-control study. Int J Cancer 2002, 100:337-341.

144. Holli K: Tamoxifen versus toremifene in the adjuvant treatment of breast cancer. Eur J Cancer 2002, 38 Suppl 6:S37S38.

145. Cummings SR, Eckert S, Krueger KA, Grady D, Powles TJ, Cauley JA, Norton L, Nickelsen T, Bjarnason NH, Morrow M, Lippman ME, Black D, Glusman JE, Costa A, Jordan VC: The effect of raloxifene on risk of breast cancer in postmenopausal women: results from the MORE randomized trial. Multiple Outcomes of Raloxifene Evaluation. JAMA 1999, 281:2189-2197.

146. Jubelirer SJ, Crowell EB Jr: The STAR (Study of Tamoxifen And Raloxifene) trial in West Virginia. W V Med J 2000, 96:602-604.

147. Jordan VC: Antiestrogens and selective estrogen receptor modulators as multifunctional medicines. 1. Receptor interactions. J Med Chem 2003, 46:883-908.

148. Jordan VC: Antiestrogens and selective estrogen receptor modulators as multifunctional medicines. 2. Clinical considerations and new agents. J Med Chem 2003, 46:1081-1111.

149. Katzenellenbogen JA, O'Malley BW, Katzenellenbogen BS: Tripartite steroid hormone receptor pharmacology: interaction with multiple effector sites as a basis for the cell- and promoter-specific action of these hormones. Mol Endocrinol 1996, 10:119-131
150. Dutertre M, Smith CL: Molecular mechanisms of selective estrogen receptor modulator (SERM) action. J Pharmacol Exp Ther 2000, 295:431-437.

151. Paech K, Webb P, Kuiper GG, Nilsson S, Gustafsson J, Kushner PJ, Scanlan TS: Differential ligand activation of estrogen receptors ERalpha and ERbeta at AP1 sites. Science 1997, 277:1508-1510

152. Jones PS, Parrott E, White IN: Activation of transcription by estrogen receptor alpha and beta is cell type- and promoterdependent. J Biol Chem 1999, 274:32008-32014.

153. Hall JM, McDonnell DP: The estrogen receptor $\beta$-isoform (ER $\beta$ ) of the human estrogen receptor modulates ER $\alpha$ transcriptional activity and is a key regulator of the cellular response to estrogens and antiestrogens. Endocrinology 1999, 140:55665578 .

154. Johnston SR, Saccani-Jotti G, Smith IE, Salter J, Newby J, Coppen M, Ebbs SR, Dowsett M: Changes in estrogen receptor, progesterone receptor, and pS2 expression in tamoxifenresistant human breast cancer. Cancer Res 1995, 55: 3331-3338.

155. Bautista S, Valles H, Walker RL, Anzick S, Zeillinger R, Meltzer $P$, Theillet $\mathrm{C}$ : In breast cancer, amplification of the steroid receptor coactivator gene AIB1 is correlated with estrogen and progesterone receptor positivity. Clin Cancer Res 1998, 4: 2925-2929.

156. List HJ, Reiter R, Singh B, Wellstein A, Riegel AT: Expression of the nuclear coactivator AIB1 in normal and malignant breast tissue. Breast Cancer Res Treat 2001, 68:21-28.

157. Osborne CK, Bardou V, Hopp TA, Chamness GC, Hilsenbeck SG, Fuqua SA, Wong J, Allred DC, Clark GM, Schiff R: Role of the estrogen receptor coactivator AIB1 (SRC-3) and HER-2/ neu in tamoxifen resistance in breast cancer. J Natl Cancer Inst 2003, 95:353-361.

158. Girault I, Lerebours F, Amarir S, Tozlu S, Tubiana-Hulin M, Lidereau R, Bieche I: Expression analysis of estrogen receptor alpha coregulators in breast carcinoma: evidence that NCOR1 expression is predictive of the response to tamoxifen. Clin Cancer Res 2003, 9:1259-1266.

159. Klijn JG, Berns PM, Schmitz PI, Foekens JA: The clinical significance of epidermal growth factor receptor (EGF-R) in human breast cancer: a review on $\mathbf{5 2 3 2}$ patients. Endocr Rev 1992, 13:3-17.

160. Klijn JG, Look MP, Portengen H, Alexieva-Figusch J, van Putten WL, Foekens JA: The prognostic value of epidermal growth factor receptor (EGF-R) in primary breast cancer: results of a 10 year follow-up study. Breast Cancer Res Treat 1994, 29:7383.

161. Tang CK, Gong XQ, Moscatello DK, Wong AJ, Lippman ME: Epidermal growth factor receptor vIII enhances tumorigenicity in human breast cancer. Cancer Res 2000, 60:3081-3087.

162. Spigel DR, Burstein HJ: HER2 overexpressing metastatic breast cancer. Curr Treat Options Oncol 2002, 3:163-174.

163. Nahta R, Hortobagyi GN, Esteva FJ: Growth factor receptors in breast cancer: potential for therapeutic intervention. Oncologist 2003, 8:5-17.

164. Morris C: The role of EGFR-directed therapy in the treatment of breast cancer. Breast Cancer Res Treat 2002, 75 Suppl 1: S51-S55; discussion S57-S59.

165. Slamon DJ, Leyland-Jones B, Shak S, Fuchs H, Paton V, Bajamonde A, Fleming T, Eiermann W, Wolter J, Pegram M, Baselga J, Norton L: Use of chemotherapy plus a monoclonal antibody against HER2 for metastatic breast cancer that overexpresses HER2. N Engl J Med 2001, 344:783-792.

166. Klijn JG, Setyono-Han B, Foekens JA: Progesterone antagonists and progesterone receptor modulators in the treatment of breast cancer. Steroids 2000, 65:825-830.

167. Ueda H, Takenawa T, Millan JC, Gesell MS, Brandes D: The effects of retinoids on proliferative capacities and macromolecular synthesis in human breast cancer MCF-7 cells. Cancer $1980,46: 2203-2209$

168. Fontana JA, Miksis G, Miranda DM, Durham JP: Inhibition of human mammary carcinoma cell proliferation by retinoids and intracellular cAMP-elevating compounds. J Natl Cancer Inst 1987, 78:1107-1112.

169. Fontana JA, Hobbs PD, Dawson MI: Inhibition of mammary carcinoma growth by reinoidal benzoic acid derivatives. Exp Cell Biol 1988, 56:254-263. 
170. Simeone AM, Ekmekcioglu S, Broemeling LD, Grimm EA, Tari AM: A novel mechanism by which $\mathrm{N}$-(4-hydroxyphenyl)retinamide inhibits breast cancer cell growth: the production of nitric oxide. Mol Cancer Ther 2002, 1:1009-1017.

171. Veronesi U, De Palo G, Marubini E, Costa A, Formelli F, Mariani L, Decensi A, Camerini T, Del Turco MR, Di Mauro MG, Muraca MG, Del Vecchio M, Pinto C, D'Aiuto G, Boni C, Campa T, Magni A, Miceli R, Perloff M, Malone WF, Sporn MB: Randomized trial of fenretinide to prevent second breast malignancy in women with early breast cancer. J Natl Cancer Inst 1999, 91:18471856.

172. Bortman P, Folgueira MA, Katayama ML, Snitcovsky IM, Brentani $\mathrm{MM}$ : Antiproliferative effects of 1,25-dihydroxyvitamin D3 on breast cells: a mini review. Braz J Med Biol Res 2002, 35:1-9.

173. Koeffler HP: Peroxisome proliferator-activated receptor gamma and cancers. Clin Cancer Res 2003, 9:1-9.

174. Stoll BA: Linkage between retinoid and fatty acid receptors: implications for breast cancer prevention. Eur J Cancer Prev 2002, 11:319-325.

\section{Correspondence}

Myles Brown, Dana-Farber Cancer Institute, 44 Binney Street, Boston, MA 02115, USA. Tel: +1 617632 3948; fax: +1 617632 5417; e-mail:myles_brown@dfci.harvard.edu 